\title{
Decentralization Implementation of HIV/Aids Programs in the Province of South Sulawesi
}

\author{
Darmawansyah $^{1}$, Muhammad Alwy Arifin², Muh. Yusri Abadi², Muhammad Al Fajrin², Anwar Mallongi ${ }^{3}$ \\ ${ }^{1}$ Professor of Department of Health Administration and Policy, Faculty of Public Health, Hasanuddin University, \\ Makassar, ${ }^{2}$ Senior Lecturers of Department of Health Administration and Policy, Faculty of Public Health, \\ Hasanuddin University, Makassar, ${ }^{3}$ Professor of Department of Environmental Health, Faculty of Public Health, \\ Hasanuddin University, Makassar
}

\begin{abstract}
In Indonesia, South Sulawesi Province is among the top 10 highest cases nationally and is among the third highest in Eastern Indonesia after Papua and Bali. This study aims to examine the decentralization of HIV/ AIDS prevention programs in the Southern Province. This research uses qualitative research method with a case study design. Data collection was carried out in South Sulawesi Province, including: Makassar City and Sidrap Regency. The location selection was based on the focus of HIV/AIDS prevention and control in South Sulawesi Province, the category of the core area. The informants in this study were the Chairperson of the Provincial AIDS Commission (KPAP) of South Sulawesi Province, the Chairperson of the Regional AIDS Commission (KPAD), the holder of the Puskesmas HIV-AIDS program and the Chair of the NGO organization concerned with HIV-AIDS in each region. The selection of informants in this study used the snowball technique. The results showed that the financing of the HIV/AIDS program in South Sulawesi Province came from the local government, the central government and assistance from abroad. Human resources for the HIV/AIDS program in South Sulawesi Province, the core focus of Makassar City and Sidrap Regency have been fulfilled and are in accordance with the qualifications consisting of doctors, nurses, laboratories, pharmacists and community health workers. HIV/AIDS logistics are provided by the central government Provincial health offices, with a one-stop system. Community empowerment in HIV/ AIDS prevention has been running so that cadres are formed; cadres in the field but this empowerment has not been maximally implemented. In order for the decentralization of the HIV/AIDS prevention program to run optimally, stakeholder cooperation is needed in its implementation so that the number of HIV/AIDS cases in the province of South Sulawesi, especially in core areas such as Makassar City and Sidrap Regency, can decrease.
\end{abstract}

Keywords: Decentralization, Prevention Programs, HIV/AIDS, South Sulawesi Province.

\section{Introduction}

Asia Pacific is the second largest region with HIVAIDS cases in the world, where $78 \%$ of new cases are

\section{Correspondent Author:}

Darmawansyah

Professor of Department of Health Administration and Policy, Faculty of Public Health, Hasanuddin University, Makassar

e-mail: darmawansyah1964@gmail.com in the Asia Pacific region. It is estimated that 5.9 million people are living with HIV in the Asia Pacific Region in 2018. While the three countries with the most cases in Asia Pacific are India, China and Indonesia. ${ }^{1}$. In 2018, new cases of HIV infection in Indonesia were the highest compared to other Southeast Asian countries. There are 46,000 new HIV infections and only 51\% of people living with HIV know their status ${ }^{2}$.

In Indonesia, South Sulawesi Province is among the top 10 highest cases nationally and is among the third highest in Eastern Indonesia after Papua and $\mathrm{Bali}^{3}$. 
Based on data from the South Sulawesi Provincial Health Office, the trend of HIV-AIDS cases has tended to increase in the last three years (South Sulawesi Provincial Health Office, 2019). Based on a report from the South Sulawesi Provincial Health Office in 2018, an estimated 16,676 people living with HIV and those found to be HIV + were around 8,821 and 10,879 who entered care, started ART 5,965 and those who are still doing ART 3,254. As for testing in the risk group in 2018, it seems that it is still far from the expected target, especially in the MSM, FSW, Risti partner, and TB group (The number of testing in the Risti partner was 2,994 while the target was 57,839; for TB patients the number of testing was 9,108 , the target was 68,054 ; MSM testing number 4,499 and target 16,594)

In the distribution of the number of HIV-AIDS cases in districts/cities in South Sulawesi, data were obtained from 8 districts/cities with the highest number of HIV/ AIDS cases, namely Makassar City (10,819 cases), Pare - Pare (561 cases), Jeneponto Regency (369 cases), City Palopo (298 cases), Wajo District (203 cases), Sidrap Regency (198 cases) and Bulukumba Regency (178 cases). The high number of HIV/AIDS cases in South Sulawesi is a commitment of all parties in order to reduce the spread of these cases ${ }^{4}$. This study aims to examine the decentralization of HIV/AIDS prevention programs in the Southern Province

\section{Materials and Method}

This research uses qualitative research method with a case study design. Data collection was carried out in South Sulawesi Province, including: Makassar City and Sidrap Regency. The location selection was based on the focus of HIV/AIDS prevention and control in South Sulawesi Province, the category of the core area. The informants in this study were the Chairperson of the Provincial AIDS Commission (KPAP) of South Sulawesi Province, the Chair of the Regional AIDS Commission (KPAD), the holder of the HIV-AIDS program at Puskesmas and the Chair of the NGO organization concerned with HIV-AIDS in each region. The selection of informants in this study used the snowball technique. The data analysis technique in this study used qualitative data analysis

\section{Results}

The implementation of HIV/AIDS prevention programs in South Sulawesi Province was assessed based on research variables, namely financing, human resources, logistics and community empowerment.
The source of funding for the HIV/AIDS Program in South Sulawesi Province consists of APBD funds and funds from foreign NGOs in the form of activities to support local government program activities in the HIV/AIDS prevention program. Based on the results of interviews related to funding with informants, the following information was obtained:

"The source of funding comes from the local government, from the previous year we got it from the Global fund, there is also the HIV Coorperate Intervention Program from the Australian government, the funds are for institutional strengthening support for KPA administrators in South Sulawesi Province" (KP, 50 years)

"The funds we have obtained are grants from a global fund" (N 28 years)

“... sourced from the APBD sir" (K, 30 years)

From the informant's statement regarding funding related to HIV prevention in the South Sulawesi province, it comes from the Regional Budget (APBD) and comes from assistance from abroad such as a global fund.

Human resources in the HIV/AIDS prevention program in South Sulawesi Province include availability/ adequacy, distribution and capacity building of HIV/ AIDS personnel. The HIV/AIDS prevention program requires sufficient personnel both in terms of numbers and qualifications, both those who work in the health office and HIV/AIDS personnel at the Puskesmas. The health workers needed at the Puskesmas in the HIV/ AIDS prevention program are doctors, laboratory staff, nurses, pharmacists and public health workers. This is as conveyed by the following informants

"In terms of resources, Alhamdulillah it is sufficient" (KD, 45 years)

"The qualifications for the HIV/AIDS prevention program are already due to the fact that there are doctors, laboratory assistants, nurses, pharmacists and public health workers involved in the HIV/AIDS program" (KP. 50 Years)

"We here consist of doctors, laboratory assistants, nurses like me, pharmacists and community health workers" (TS, 30 years) 
The distribution of HIV workers is still a concern in the utilization of human resources in the HIV/AIDS prevention program in South Sulawesi Province with a focus on Makassar City and Sddrap District. The distribution of Puskesmas personnel determines the availability of HIV/AIDS personnel at the Puskesmas. Puskesmas located in urban areas are the main choice for health workers. Meanwhile, health centers that are far from urban areas are still minimal and have not yet fulfilled service needs, due to problems in access (affordability), safety factors, availability of needs, and housing.

"The distribution of HIV/AIDS program personnel in the city of Makassar already exists in every puskesmas, but sometimes there are prevention programs that have not run optimally" (K, 45 years)

“.. if our distribution here is good ..." (R, 40 years)

Capacity building is carried out in the form of providing training to HIV/AIDS personnel to improve skills in services and recording and reporting

"There is always capacity building, what's more with the assistance from a global fund which then organizes training activities for us" (K, 45 years old)

“.. So there are already training activities for fellow HIV/AIDS program holders, ... (N, 28 years old)

The logistics of the HIV/AIDS program is a supporter of the HIV/AIDS response program services in South Sulawesi Province. In general, the logistics procurement for the HIV/AIDS program in the Province of South Sulawesi comes from procurement from the Province and the APBN.Based on the results of interviews related to logistics with informants, the following information was obtained.

"Through the mechanism of the Ministry of Health then to the Provincial Health Office then the Pharmacy Warehouse then the NGO/Partner Officer" (DS, 40 years)

"For logistics at our puskesmas it is sufficient, but during this pandemic there is a lack of logistics but there is no vacancy in our puskesmas" ( $\mathrm{K}, 45$ years).

Community empowerment has been stipulated in various government policies, both central and local, as a form of community participation mechanism from the grassroots level in supporting access to health and social services for those infected. Community empowerment is an important strategy to eliminate discrimination against people infected with HIV/AIDS. Community participation in the context of non-governmental organizations (NGOs), at the operational level is the role of KPAD. KPAD conducts guidance and empowerment in local non-governmental organizations

Currently, there are several NGOs engaged in HIV/AIDS prevention programs in South Sulawesi Province, namely the Gaya Celebes NGO, YMH, YPKDS, a fraternal organization for drug victims. The empowerment activities carried out by NGOs are training, assistance in taking medication, distribution of condoms, counseling about HIV, reproductive health and others. The Health Office in this case took part in providing material on training activities conducted by NGOs.

.... providing support for activities in the form of funds that they must be accountable for every year, each NGO is given a number of millions of assistance, for which they are accountable every year. Then there may also be empowerment activities such as training training, then there are also empowerments at the level of NGOs like them and this is the health office also providing material during activities at these local NGOs ... (AF, 42 years).

The budget for NGO activities for HIV/AIDS prevention and control programs comes from grant funding from abroad such as USAID, AUSAID and the Golbal Fund. However, currently the assistance from USAID and AUSAID has closed.

... our funding runs with funding assistance from grants from abroad, namely the global fund. .. (N, 28 Years)

\section{Discussion}

The South Sulawesi Provincial Government funds the HIV/AIDS program from the APBD. Funding from APBD in 2010 to 2014-2020. This funding is coordinated by KPAD and the Health Office and distributed to SKPDs or agencies that work on HIV/ AIDS prevention programs in districts/cities. Funds for HIV/AIDS programs in the Health Office also increase every year. However, the absorption rate of the budget only reaches $20-30 \%$. 
Apart from the budget originating from the APBD, funding for the HIV/AIDS program in South Sulawesi Province is also greatly helped by the funding that comes from foreign aid. International institutions are institutions that have high resources, financial resources and technical capabilities, whose role in the HIV/AIDS prevention program in South Sulawesi Province is not to create new programs but to provide support to local governments in implementing HIV/AIDS programs in South Sulawesi Province ${ }^{5}$.

So far, the budget needs sourced from abroad for HIV/AIDS prevention have been met by the Global Fund, the Australian Department of Foreign Affairs, the United States Support Fund (USAID), agencies originating from the United Nations and International Non-Governmental Organizations (NGOI). However, the sustainability of funding from abroad cannot be ascertained, because every NGO has a certain contract period.

The decentralization of the HIV/AIDS prevention program urgently needs strengthening of human resources in terms of numbers, qualifications, distribution and capacity building of HIV/AIDS personnel at all levels, including the Health Office, health centers, hospitals, NGOs and cadres. Human resources engaged in HIV/ AIDS programs include field personnel (peer educators, outreach workers, field program supervisors, field level program managers), service levels (counselors, specialists, general practitioners, laboratory staff, nurses, administrative officers, nutritionists, midwives, case managers) and coordination/KPA levels in districts/cities (program managers, monitoring and evaluation officers, and administrative managers). Human resources as input in the health system will greatly affect the operation of the health system itself. ${ }^{6}$. The availability of human resources greatly affects the running of the HIV/AIDS $\operatorname{program}^{7}$..

Logistical management of HIV/AIDS prevention programs includes planning, procurement, storage, distribution, use and control of drugs and medical equipment for prevention, diagnostics and therapy. Logistics management in the health system is carried out by the ministry of health at the central level and health offices at the sub-national level. The logistics management system is expected to guarantee that the program implementation must arrive at the beneficiaries in a timely manner, fulfilling their needs with guaranteed quality. Procurement of drugs and medical equipment for HIV/AIDS prevention and therapy is currently still dependent, especially from foreign assistance, except for ARVs and some reagents which are fully prepared by the Ministry of Health. In general, policies related to pharmaceutical preparations are regulated in Government Regulation No. 72/1998 on Safeguarding Pharmaceutical Preparations and Medical Devices, which mandates the procurement of methadone and ARVs prepared by the central government. Apart from procurement by the central government, logistics for HIV/AIDS are also provided by the South Sulawesi Provincial Health Office.

Provincial health office decentralization policy. Distribution to districts/cities uses a one-door system. Currently, the logistics supply chain from the Provincial Health Office to service units such as puskesmas and hospitals is running well, except for areas with difficult geographic conditions. The Regency/City Office submits logistical requests every month to the Provincial Pharmacy Installation according to the number of cases in each Health Office. This is to ensure the availability of logistical supplies at the Health Office and service units ${ }^{8}$.

Empowerment of MARPs and PLWHA communities is the key to independently providing sustainable HIV/ AIDS services based on the community's need to live healthily, both to protect themselves from HIV infection and to maintain the quality of life of PLWHA.

In carrying out their duties, NGOs receive budget assistance from KPADs with assistance from international donors. However, the activities of NGOs operating in districts/cities in South Sulawesi province are not well coordinated so that there are still many overlapping activities between NGOs. Even some activities overlap with activities carried out by the Puskesmas. So that the issue of coordination between NGOs and the government is still something that must be considered in the context of the success of the HIV/AIDS program in South Sulawesi Province. The current community empowerment is related to the implementation of HIV/AIDS prevention programs at the District/City Health Office. The cultural approach is one of the factors that must be considered in the HIV/ AIDS prevention program ${ }^{9}$.

The issue of communication between stakeholders was also found by Fritantus and Rukminingsi (2013) in their research in Surabaya, that communication between stakeholders is highly expected in the HIV/ 
AIDS prevention program. ${ }^{10}$. Communication between stakeholders will affect other needs such as financing, provision of human resources, and others. The sectoral ego is still an obstacle in HIV/AIDS prevention programs ${ }^{11}$.

\section{Conclusions and Recommendations}

This study concludes that the financing of the HIV/ AIDS program in South Sulawesi Province comes from the local government, the central government and foreign assistance. Human resources for the HIV/AIDS program in South Sulawesi Province, the core focus of Makassar City and Sidrap Regency has been fulfilled and is in accordance with qualifications consisting of doctors, nurses, laboratory staff, pharmaceutical workers and public health workers. HIV/AIDS logistics are provided by the central government Provincial health offices, with a one-stop system. Community empowerment in HIV/ AIDS prevention has been running so that cadres are formed in the field but this empowerment has not been maximized in its implementation.

Ethical Clearance: Obtained from Hasanuddin University ethical committee

Source of Funding: Self

Conflict of Interest: Nil

\section{References}

1. UNAIDS. HIV and AIDS in Asia \& Pacific Regional Overview2019.

2. UNAIDS. Data Section-Compare Area. Retrieved 2019.

3. Kemenkes RI. Laporan Perkembangan HIVAIDS \& Penyakit Infeksi Menular Seksual (PIMS) Januari-Juni 2019. Jakarta: Kementerian Kesehatan;2019.

4. Adam A, Badwi A, Palutturi S. Analysis of Factors Associated with Self-Stigma (PLHIV) on the HIV and AIDS Incidencein Jongaya Positive Care Supporting Group of Makassar City. Indian
Journal of Public Health Research \& Development. 2019;10(11).

5. Suswani A, Arsin AA, Amiruddin R, Syafar M, Palutturi S. Factors related quality of life among people living with HIV and AIDS in Bulukumba. International Journal of Community Medicine and Public Health. 2018;5(8):3227-3231.

6. Masupe T, El-halabi S, Chebani T, et al. Impact of health system inputs on health outcome: a multilevel longitudinal analysis of Botswana National Antiretroviral Program (2002-2013). 2016.

7. Darmawansyah, Rahmadani S, Syafar M, Balqis, Arifin A. The analysis of factors affecting the use of VCT service for high-risk group infected with HIV/AIDS in Makassar. International Journal of Research in Health Sciences. 2014;2(4).

8. Resubuna TF, Darmawansyah MTA, Amiruddin R, Manyullei S. HIV/AIDS Control Program in Health Office of Jayawiya District: Empowerment and Logistic Study. Indian Journal of Physiotherapy \& Occupational Therapy. 2019;13(4):29. Arifin MA, Maidin A, Darmawansyah. The Ethnographic Assessment of Program Policy on HIV/AIDS Countermeasures in Regency of Bulukumba, South Sulawesi Province 2016. International Journal of Sciences: Basic and Applied Research. 2016;27(2):106-112.

10. Fritantus Y, Rukminingsih N. IMPLEMENTASI KEBIJAKAN PENANGGULANGAN HIV DAN AIDS DI KOTA SURABAYA (Kajian Peraturan Daerah Kota Surabaya Nomor 4 Tahun 2013, Studi Kasus di Puskesmas Putat Jaya, Kota Surabaya). JPAP: Jurnal Penelitian Administrasi Publik. $2015 ; 1(01)$.

11. Aji PGP, Hidayat Z, Rostyaningsih D. Implementasi Perda Nomor 3 Tahun 2010 Tentang Penanggulangan HIV/AIDS Di Kabupaten Semarang. Journal of Public Policy and Management Review. 2016;5(3):410-422 